these cases except the third. As regards inflamed hydrocele, if the contained fluid is really purulent, iucision and drainage are necessary. Should the tunica be much thickened or degenerated, partial or entire removal may be advisable in addition. But when the inflammation has not reached the stage of suppuration, the case is best left to nature. The hydrocele is undergoing a process of spontaneous cure, as after injection, by adhesive inflammation. Evidence of this event having occurred is frequently met with in performing operations for the removal of scrotal elephantiasis. The cavity of the tunica is sometimes found to have been obliterated and occupied by a thin layer of fibrous or cicatricial tissue, which glues together the parietal and visceral portions of the sac. This result is sometimes due to the setons, issues and moxas which are applied to the fundus of scrotal tumours by native surgeons and sometimes to inflammatory changes occurring in the hypertrophied scrotal tissue. We have seen large phlegmonous abscesses in the scrotal wall and found the tunica of the same side distended with clear fluid, showing perhaps a few flakes of lymph floating in it. The alternative in the circumstances indicated by $D r$. Hatch is not between injection and incision, but between incision and castration. It is very seldom in these cases, more especially the more chronic, however distended or thickened or degenerated the tunica may be, that the testes are structurally diseased. They may be flattened out, or the epididymis may be separated from the body of the testicle, but they are neither wasted nor indurated; and such being the case, castration is both an unnecessary and risky mutilation. In removing the tunica, whether in whole or in part, it is well to identify it carefully and distinguish it from its fascial coverings which may also be thickened, but are seldom if ever degenerated. If the tunica is accurately identified in the section made by the incision, it can be stripped off the fasciæ and cord without much difficulty or bleeding, and it can also be dissected or scraped off the epididymis or testicle without injuring either. If the fascia are very voluminous, a wing can be cut off with scissors on either side of the cord. Of course if there is any malignant disease of the tunica, such as sarcoma or auy disorganization or destructive atrophy of the testicle, castration is the simplest and best operation; but we are inclined to think that the older surgeons resorted to it too readily, and are equally certain that a better knowledge of the pathological anatomy of the testicle and its coverings and improved means of operating deliberately have led modern surgeons to adapt their practice in dealing with conditions such as we have indicated to the conservative spirit of the age.

\section{TYPHOID FEVER.}

Tнe subject of enteric fever in the European Army occupies a dozen pages of the twentysixth annual report of the Sanitary Commissioner with the Government of India, and it is agreeable to note therein that the useless and pernicious statistical method of diagnosis as adopted by the special commission to enquire into the alleged increase of enteric fever has, and let us hope finally, been abandoned. As was pointed out at the time of our consideration of that report, the application of the statistical method and the building a theory thereon was radically wrong, misleading, and not adapted to the scientific advances of the day, and it was not by such means that the question as to the prevalence of enteric fever in Lucknow, Meerut, and elsewhere could be settled, nor could the causes of such suspected prevalence be thus ascertained. The issue, we observed, could only be decided by a study of the clinical features of the malady aided by the adoption of the most recent bacteriological, microscopical and chemical tests, whilst a clue to the causes of its prevalence could be only obtained by the employment of those well-known methods of enquiry pursued in Eugland and elsewhere at the time of the prevalence of the disease and on the spot.

A beginning has been made in this direction. The bacillus typhosus has been found, not by an Indian Medical Officer, but by Professor Bernhard Fischer of Kiel, in Germany, in specimens of spleen and mesenteric glands forwarded to that distinguished bacteriologist from two cases of enteric fever. The transmission of the material to Germany for the purpose of identification was probably prompted by a desire to have it examined by an observer familiar with the necessary manipulations and with the appearance and reactions presented by the typhoid micro-organism aud the identification may be 
accepted as more authoritative than if it had been announced by an Indian observer, still we cannot help remarking that it seems a pity that India should have to resort to Germany for work of this kind. We would here repeat what we have frequently urged in this journal, that the arrangements for the scientific study of disease in India are not such as we should wish or as the circumstances of the country render desirable and practicable.

The discovery however of the bacillus typhosus by Professor Fischer in these two specimeus, and later on by Surgeon-Major Ranking in the urine of a third case, leads, as the Sanitary Commissioner remarks, to the conclusion that at least some of the fatal fevers of India with intestinal lesious are identical with the enteric fever of Europe. And that hence the source of real enteric fever in India must be looked for in the contamination of ingesta, and climate must be considered a secondary influence. This is a most important conclusion, and doubtless will be followed by practical results. It is only necessary to read the extracts furnished in the report of the sauitary condition of some of the military stations to be satisfied that all is not above suspicion.

Impure or suspicious water-supply, sub-soil pollution, contaminated milk-supply, close proximity of trenching grounds to barracks, and defective drainage seem to have played a leading part in the local incidence of the disease. These are conditions which are commonly associated with typhoid fever in Europe and are within the practical range of speedy removal. The most important point accordingly is to remove these local conditions which are so detrimental to the health of the young soldier. This may not be an easy matter as regards that part of it which relates to private supplies from bazars adjacent to cantonments; but there should be no difficulty, or if there is steps should be at once taken to have it removed, in providing in every military station a water-supply above suspicion, a pure milk-supply, and proper sanitary arrangements for the disposal of sulliage and the treatment of refuse and sewage.

It is not asking anything extraordinary that special attention should be paid to the condition of the wells in military cantonments, that they should be properly covered and not open as at present; that their waters should be periodically analysed; that suspicious wells should be shut up, and that all wells should be regularly cleansed.

It is worthy of note that Fort William, which has an excellent water-supply, had of enteric fever an admission rate per 1,000 of the strength of only 9 and no deaths, against Bareilly and Mhow, with admission rates of 7.7 .9 and 75.4 per 1,000 of strength, and a mortality of $23 \cdot 77$ and 17.89 per 1,000 respectively. The bazars of Calcutta are not conspicuous for their sanitary condition. If they differ from bazaars in Upper India, it is in possessing a purer water-supply, and it is in this respect also that we think Fort William differs from many of the military cantonments in other parts of India.

There are some interesting statements in the Sanitary Commissioner's report. 'The following table shows the young suldier under 24 to be five times more liable to enteric fever than the soldier above 30 :-

\begin{tabular}{|c|c|c|c|c|c|c|c|c|}
\hline & \multirow{3}{*}{ YEAR. } & & \multicolumn{6}{|c|}{$\begin{array}{l}\text { AORTALITY FROM ENTERIC FEVER AND RATIO OF } \\
\text { LIABILITY TO IT AT DIFFERENT AGES. }\end{array}$} \\
\hline & & & \multicolumn{2}{|c|}{24 and under. } & \multicolumn{2}{|c|}{25 to 29 . } & \multicolumn{2}{|c|}{30 to 34 . } \\
\hline & & & 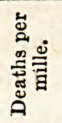 & 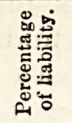 & 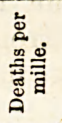 & 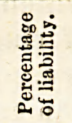 & 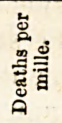 & 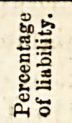 \\
\hline 1889 & $\ldots$ & $\ldots$ & $9 \cdot 81$ & $64 \cdot 50$ & $3 \cdot 25$ & $21 \cdot 37$ & 1.83 & $12 \cdot 03$ \\
\hline
\end{tabular}

This, however, only bears out the experience gained of this disease in other countries, and though a statistical fact of importance only shows how necessary it is under the present army system obtaining in India, that every possible sanitary precaution should be taken to protect the young soldier on his arrival in India.

The most curious, and so far inexplicable, fact noted in the report is the great immunity from enteric fever which the native troops and the native prisoners in jails enjoy in comparison with the European troops. This is summed up in the following tabular statement:-

\begin{tabular}{|c|c|c|c|c|}
\hline & $1877 \mathrm{TC}$ & 886. & 18 & \\
\hline & Admissions. & Deaths. & Admissions. & Deaths. \\
\hline $\begin{array}{l}\text { European troops } \\
\text { Native troops } \\
\text { Jail population }\end{array}$ & $\begin{array}{r}8 \cdot 9 \\
\cdot 2 \\
\cdot 2\end{array}$ & $\begin{array}{r}3 \cdot 15 \\
\cdot 10 \\
\cdot 10\end{array}$ & $\begin{array}{r}22 \cdot 9 \\
\cdot 2 \\
\cdot 4\end{array}$ & $\begin{array}{r}6 \cdot 11 \\
\cdot 07 \\
\cdot 16\end{array}$ \\
\hline
\end{tabular}

The comments made on this peculiar fact by the Sanitary Commissioner are that it may be 
due to "1st, racial peculiarity ; $2 \mathrm{nd}$, tolerance acquired in lapse of time, generation after generation living saturated in filth; $3 \mathrm{rd}$, comprative immunity of native adults as a result of prevalence of the disease among native children. This last explanation is put forward by BrigadeSurgeons Hamilton and Cleghorn and SurgeonMajor Holmes, of Lucknow, as probable from facts in their experience. But the point cannot be settled till more is accurately known regarding the infantile diseases of natives."

There is much to be said on the side of acquired tolerance. When immunity can be gradually obtained by inoculative processes, it opens up a wide field for speculation on immunity acquired by everything included under the general term of acclimatization.

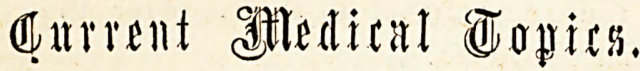

\section{PARASITES IN THE BLOOD.}

Dr. Patrick Hehir is engaged in some interesting observations on the microscopical organisms which he has found in the blood of patients suffering from malarial fever, cholera, and dysentery. In the case of malarial patients, the Laveran microbes according to Dr. Hehir are not simple amœboid bodies, but infusoria with flagella, and whenever they are motionless, it is because the parasites have not yet got their flagella fully developed, or on account of an accident, these have been torn off. The most frequently met with organisms are an actively moving body highly refractile in the centre, and having a single flagellum and a star-shaped body with many flagella. The filamentary appendages of these two bodies, Dr. Hehir is under the impression, have not been noticed by other observers owing to their extreme tenuity, transparency and excessively rapid motion similar to that of the cilia of ciliated epithelium. 'The star-shaped body, Dr. Hehir proposes to name Homatomona malaria stellata. Another polymorphic infusorian has been detected by $\mathrm{Dr}$. Hehir in the blood and dejecta of cholera patients, which moves very rapidly across a high power field. A similar hæmatozoon seems to be present in dysentery. We shall await with interest Dr. Hehir's promised paper on the subject.

\section{INDIA AND THE INTERNATIONAL CONGRESS OF HYGIENE.}

WE reproduce the following from a recent issue of the Lancet:-

"We are pleased to record that a strong Indian Committee has been formed in Loudou to ensure the adequate representation of Indian interests at the forthcoming Congress. The Committee is composed of leading Anglo-Indian officials and prominent East India merchants, together with other non-officials. Thus what has often been termed the Second India will have voice in the Congress. By this is meant the non-official India, and it embraces very vast interests. Finally there are three native Iudians on the Committee-namely, Mr. Dadabhoy Nowrojee, Mr. B. M. Malabari, and Mr. M. M. Bhownaggree, C.I.E. 'These three gentlemen are Parsees, but several prominent Hindoos and Mahomedans have been asked to join the London Committee. In India the Chambers of Commerce of Bengal, Bombay, Kurrachee, and Upper India have already appointed delegates, thus following the example of the Indian Government and the Municipal Corporation of Calcutta. Other leading municipalities and the syndicates of the Indian universities have intimated their intention of nominating delegates, and we are especially pleased to hear that some uative princes have promised aid, either by sending subscriptions or deputing representatives. In one respect, however, prompt and energetic action is necessary. The London Indian Committee have strongly urged upon the Secretary of State for India the desirability of securing the attendance at the Congress of a certain number of native experts. It is understood that the home authorities for India thoroughly approve of this proposal. Surely, on further consideration, Lord Lansdowne's Government will be equally desirous to see this carried out. There can be no lack of suitable candidates; and how can the native populations of India be taught to appreciate the benefits of sanitation if we do not have native Indians as members of the Congress of Hygiene? The suggestion we threw out last week as to the advisability of discussing the factory legislation proposed for India has, we are informed, been already adopted. 'The mill-owners of India will, in any case, have their say at the Congress, and we hope that the native work-people will find their interests equally well befriended."

The necessity of India being adequately represented at the Congress is too obvious to require argument or persuasion.

DEPUTATION OF DR. W. J. SIMPSON TO THE INTERNATIONAL CONGRESS OF HYGIENE.

THe Chairman of the Calcutta Municipal Corporation has raised the question of deputing Dr. Simpson to attend the Congress. This is an admirable proposal, and we earnestly hope that the Corporation will accept it promptly, and make liberal arrangements to enable Dr. Simpson to inform the Congress regarding the sanitary reforms which have been already accomplished in the capital of India, and to inform himself 